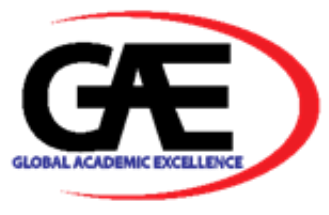

www.ijlgc.com

\title{
THE SPREAD OF COVID-19 FAKE NEWS ON SOCIAL MEDIA AND ITS IMPACT AMONG MALAYSIANS
}

\author{
Suhaila Ngadiron ${ }^{1}$, Azureen Abd Aziz ${ }^{2}$, Saheera Sardar Mohamed ${ }^{3}$ \\ 1 Centre of Liberal Arts and Languages, INTI International University, Malaysia \\ Email: suhaila.ngadiron@ @ewinti.edu.my \\ 2 Centre of Liberal Arts and Languages, INTI International University, Malaysia \\ Email: azureen.abdaziz@newinti.edu.my \\ 3 Communication Department, University Putra Malaysia, Malaysia \\ Email: saheerasardar@yahoo.com \\ * Corresponding Author
}

\section{Article Info:}

\section{Article history:}

Received date: 15.02 .2021

Revised date: 15.03 .2021

Accepted date: 20.03 .2021

Published date: 31.03 .2021

\section{To cite this document:}

Ngadiron, S., Abd Aziz, A., \& Mohamed, S. S. (2021). Spread of Covid-19 Fake News on Social Media and Its Impact among Malaysians. International Journal of Law, Government and Communication, 6 (22), 253-260.

DOI: $10.35631 /$ IJLGC.6220024.

This work is licensed under CC BY 4.0

\section{()(1)}

\begin{abstract}
:
The problem of spreading fake news is not something new in this globalized era. However, nowadays, it has become a common trend among our Malaysians. In the current situation of our country Malaysia, the platform of social media is portrayed as the most suitable platform to spread rumors and fake news all over. Since the country is plagued by the Covid-19 pandemic, a variety of news and stories are served before our eyes on various social media such as WhatsApp, Facebook, Twitter, Telegram, or Instagram. These deleterious actions can actually have a detrimental effect on social, economic growth, national security as well as psychosocial impact. Findings show that information easier to obtain; easily believe in whatever they read and selfsatisfaction are the main reasons for an individual who tends to have the tendency to spread fake news.
\end{abstract}

Keywords:

Fake News, Covid-19, Social Media, Society 


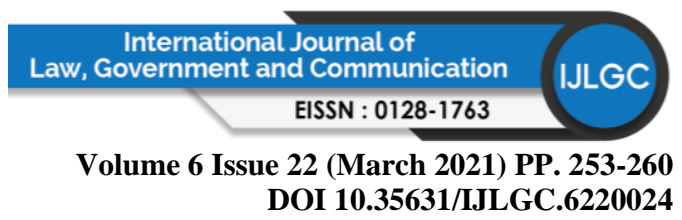

\section{Introduction}

The media plays an important role in conveying information to the community. In today's era of globalization, through the internet, the role of the media is getting easier, but more challenging. The existence of the internet helps to speed up the process of delivering news and all sorts of information. Additionally, social media also plays a role in making the Malaysian society more sensitive to the surrounding situation and strengthen the relationships among individuals, but the community should be more careful because there is fake news designed solely to attract the attention of netizens and become a hot or trending issue. Thus, this situation is very perturbing because there are news whose truth is uncertain and can create hatred and provocation among multiracial society. This situation is increasingly worrying when some Malaysians tend to spread fake news without checking the truth (Farris Shahiran, 2019). The information or news disseminated individually or in groups may not be as accurate as it seems to or better known as hoaxes. This term means information or news that are uncertain (Juditha, C., 2018). As the world faces the devastation of Covid-19, the chain of fake news spreading rapidly are causing many adverse effects on society and the country. Therefore, this study aims to look at the causes of the spread of fake news and its impact on society.

\section{Literature Review}

The random transmission of fake news has brought problems to individuals, communities and nations. The fake news spread by irresponsible parties can result to big and serious probems later on. Various warnings have been issued by the government, but the spread of fake news is becoming more and more common. A study conducted by the Institute of Strategic and International Studies Malaysia (ISIS) shows that 70 percent of the 363 fake news related to government action is in dealing with Covid-19 and the spread of viruses in the community (Wan Mohd Nor, 2020).

As have been stated in MyMetro website, an article written by Nurul Hidayah (2020), the Communications and Multimedia Commission (MCMC) has identified 18 suspects out of 43 cases of spreading false news about Covid-19. SKMM in its statement informed that there are six suspects already charged in court. The statement informed that MCMC and the Royal Malaysian Police (PDRM) are working together through the Cyber Crime Committee to deal with the continuous spread of fake news, especially about Covid-19, which can be confusing and create conflicts among the netizens.

The World Economic Forum lists the dissemination of false information and false news as one of the world's major global risks (M. Saraswathi, 2020). According to a research conducted by Prof. Roberto Cavazos (2019) and artificial intelligence and cyber security company CHEQ, fake news has caused losses to the global economy amounting to about US \$ 78 billion (RM322 billion) a year. It affects everything from public health to the economy. Their report, entitled The Economic Cost of Bad Actors on the Internet, mentions the high cost of health epidemics due to fake news. It cites an analysis of 14 million Twitter chats conducted by the Nature Researh Journal that found fake accounts responsible for playing an unbalanced role in disseminating articles from unreliable sources. It affects everything from public health to the economy.

According to Giselle, R. \& Turkey A., (2020) there are several factors that influence an individual to accept or decline a hoax news. The first factor is age. This has been researched by Hartzel et al., 2016 which shows that $83 \%$ of adults who use social media are in the age 


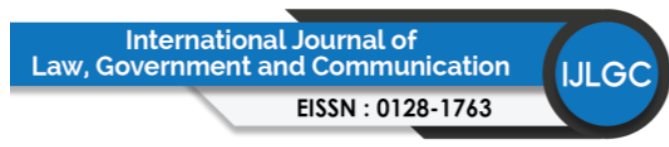

Volume 6 Issue 22 (March 2021) PP. 253-260

DOI 10.35631/IJLGC.6220024

range of 18-29 years. The second factor is gender, where there are several studies stating that women are less likely to explore new technologies (Allyn, 2003; Li, Records, \& Fougere, 2004; Shashaani \& Khalili, 2001). The third factor is education where there are studies showing that the less educated are more likely to believe in the acceptance of fake news (Allcott \& Gentzkow, 2017). The fourth factor is culture. For example, Saudi Arabia has a culture with a high level of power, maturity, morality and morality (Al-Sukkar, 2005; Karim, 2017).

The spread of fake news made by irresponsible parties is very inappropriate because the matter has a negative impact on society. The attitude of some who like to make and spread their assumptions will cause problems that are more complicated.

\section{Statement of Problem}

Recently, the country has not only been threatened with the spread of the Covid-19 epidemic, but has also worsened the situation when the 'epidemic' of fake news has become increasingly difficult to control, causing chaos among the community. This activity with the intention of 'fun' or evil clearly exposes society to fear, including triggering panic and insecurity.

The effect of spreading this fake news can lead to loss of life and make a huge impact in a society. As a result of believing rumors that drinking alcohol can help cure coronavirus infection, a total of 44 Iranian individuals died. According to a report by the Islamic Republic News Agency (IRNA), the deaths were due to the spread of news that alcohol could cure corona outbreaks. But unfortunately the illegally processed alcoholic beverages cause poisoning. Many victims are desperate to protect themselves from infection. It also encourages them to take the drink that is made illegally (Asyikin, 2020).

Next, Sarfarizmal, (2020) in his article wrote about the spread of fake news claiming 13 Cabinet Ministers confirmed positive Covid-19. The news that spread through social media can not only add to the people's anxiety, but also give a bad image to the entire national leadership. Not only that, there are also irresponsible parties who deliberately spread graphic images of certain leaders on social media accompanied by controversial words that allegedly came out of the leader's mouth. The impact of this act is enormous. These false news are spread with the intention of confusing, manipulating, and inflaming the feelings of the people. Thus, false perceptions of an individual or his organization arise (Li \& Fougere, 2004).

\section{Research Questions}

What is the cause of the spread of Covid-19 fake news on social media and its impact among the Malaysian community?

\section{Research Objective}

Identify the cause of the spread of Covid-19 fake news on social media and its impact among the Malaysian community.

\section{Purpose of the Study}

The purpose of this study is to see the spread of fake news Covid-19 on social media and its impact among Malaysian society. After identifying the cause of the spread of the fake news, the researcher will give a look at its impact on society. 


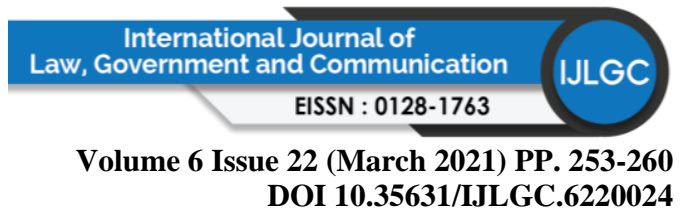

\section{Research Methodology}

This study is a survey in the form of a survey that uses a questionnaire. The use of the questionnaire aims to obtain a lot of important and more accurate information from the respondents, then more respondents can be collected. The focus of this study is on the community that has, browsing and following the development of social media in Malaysia.

The questionnaire of this study was formed and divided into four main sections, namely sections A, B and C. Section A explains the background of the respondents. Part B explains the form of hoax (fake news) posted on social media and Part $C$ the effect of fake news shared on social media. All these instruments are designed so that the research questions studied can meet the objectives of the study. The questions are based on the objectives of this study and are in the form of a likert scale which is measured based on the scale of (1) strongly disagree,

(2) disagree, (3) uncertain, (4) agree, and (5) strongly agree.

\section{Findings}

Based on the issues that have been explained in this article, the researcher has made the findings of the study that need to be discussed. Among them are the factors that contribute to the spread of fake news among the Malaysian community and its impact on society.

The tests were done for 100 respondent that were chosen randomly from three different universities, namely University Kebangsaan Malaysia, University Putra Malaysia dan University Malaya. The researcher obtained data from the objective test that was in the form of multiple choices questions.

Table 1: Summary of Respondents

\begin{tabular}{lccc}
\hline \multicolumn{1}{c}{ Universiti } & $\begin{array}{c}\text { Number of } \\
\text { respondents }\end{array}$ & Age & Survey Method \\
\hline Universiti Malaya & 33 & $20-30$ years old & Online \\
Universiti Putra Malaysia & 34 & $20-30$ years old & Online \\
Universiti Kebangsaan Malaysia & 33 & $20-30$ years old & Online \\
Total & $\mathbf{1 0 0}$ & & \\
\hline
\end{tabular}

Table 2: Mean and Percentages Cause of the Covid-19 Fake News

\begin{tabular}{llcc}
\hline No. & Item & Mean & SD \\
\hline 1. & To fill free time & 3.61 & 1.228 \\
2. & Self satisfaction & 4.01 & 0.891 \\
3. & Easy to believe & 4.06 & 0.817 \\
4. & To release stress & 3.79 & 0.986 \\
5. & Information that easily available & 4.09 & 0.826 \\
& Total & $\mathbf{3 . 9 2}$ & $\mathbf{0 . 5 6 1}$ \\
\hline
\end{tabular}

\section{Cause of Spread Fake News}

Analysis from this study showed that the factors that contribute to the spread of fake news among the Malaysian community in this digital age are information that is easily available. This can be proved by looking at the respondents' response to the research item. Table 2 stated highest mean 4.09. With the dumping of information circulating on the Internet has resulted in 


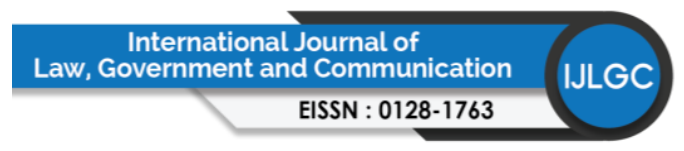

Volume 6 Issue 22 (March 2021) PP. 253-260

DOI 10.35631/IJLGC.6220024

a lot of fake news being spread. To make matters worse, the attitude of Internet users who are itchy and quick to share the news even though the source has not been confirmed or doubted is worrying. Whether you want to be an unqualified journalist on the internet or the type who always wants to be the first to spread the news causes the spread of fake news to spread so much that it drowns out the real news. The community is now more interacting in the virtual world that accumulates in it the overflow of news obtained through various channels such as newspapers, magazines, mass media (WhatsApp, Facebook, Instagram, and YouTube) and so on. By typing a keyword into an internet search engine, every detail of the required information will be displayed. The issue is, is this information easy to obtain, able to be filtered and verified its authenticity. But if the news is an authentic thing, then it is good for those who receive it, but if it is the opposite then surely it will invite hostility and discord between communities (Björn Ross, 2018).

People in this country are seen to be less sensitive to the dangers of fake news in their daily lives and enjoy sharing without a motion to check. One of the reasons is they easily believe in whatever they read (mean 4.06). This happen when the minds of people who are increasingly shallow in knowledge and no longer practice the culture of reading material that is not from the internet. The internet should be the depth of knowledge but that knowledge comes from the understanding and intellect that is driven by the intelligent mind and can separate logic or not with the strength of content in the human brain itself. At the same time making the reader too lazy with anything that is bribed and quickly deceived by short news and sensations. According to Björn Ross (2018), in the era of advanced globalization and in line with the sophistication of global technology, it is not an impossible and difficult thing for a person to disseminate information presented to society.

The habit of spreading the earliest news or breaking news syndrome by unqualified 'journalists' on social media platforms such as Facebook, Twitter, WhatsApp and Telegram is very worrying. The information disseminated by these groups is questionable, as the majority only tend self-satisfaction and want attention (mean 4.01). According to the Senior Lecturer of the Clinical Psychology and Behavioral Health Program, Faculty of Health Sciences, Universiti Kebangsaan Malaysia (UKM), Dr Shazli Ezzat Ghazali revealed that the syndrome can be associated with mental and emotional problems. Most individuals who commit such acts have low self-esteem issues and feel insecure. The habit of spreading this false news exists in a person due to the urge to gain self-satisfaction (HM, 2020).

\section{The Effect of Spreading Fake News}

The spread of fake news about Covid-19 is seen to have a huge impact from a psychosocial aspect. David DeSteno (2020) a psychologist from Northeastern University, states the high number of deaths has led to anxiety and fear. According to him, there is an extreme and unbalanced psychological fear or psychological fear. This psychological fear is due to a combination of emotional factors and limited knowledge of Covid-19. Various false information adds to the concern. This is compounded by the fear through irrational thinking that the people around are all carriers of the Covid-19 virus. For example, as faced by stall traders at the Kempas Community Center, Johor Bahru who were slandered for allegedly being in the Covid-19 Red Zone. The actions of some irresponsible parties to spread the fake news caused the visitors of the Community Center to be afraid to set foot in the area. At the same time, it affects the income of traders there up to 30 percent. The spread of such untrue news seems to 'pour sand into the rice cooker' of their innocent (Sarfarizmal, 2020). 


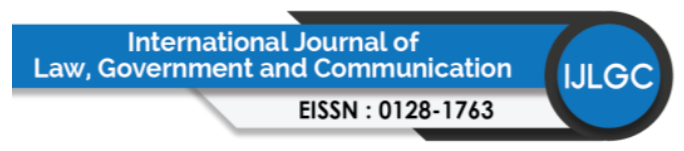

Volume 6 Issue 22 (March 2021) PP. 253-260

DOI 10.35631/IJLGC.6220024

In a time when the world is struggling with this epidemic, many are plagued with the attitude of easily believing false information. The effects of uncertainty about information cause oneself to be easily influenced by unauthentic news. According to Adam Kucharski (2020), many individuals are unwise to identify misleading information especially on social media. Among the reasons is not knowing how to filter the true information and the impact of society will be too hasty in receiving and disseminating information. For example, in a panic-buying situation, consumers flock to shops and supermarkets to buy goods in large quantities and outside daily necessities following the government's implementation of the Movement Control Order (PKP). If the state of panic is not curbed, it can inevitably lead to worse conditions that can lead to rejection, misunderstanding, conflict and strife. Following that, the state Ministry of Domestic Trade and Consumer Affairs (KPDNHEP) advised the public not to rush to purchase daily necessities because there is sufficient stock of goods (Amir Mamat, 2020).

Another effect that can be seen is that there is a society that is prejudiced and likes to blame others. According to Sapora Sipon (2020), as Covid-19 originated from Wuhan, China, antiAsian sentiment increased drastically. When individuals behave in confused and confused emotions, they can make irrational choices. There are people who are already prejudiced and such a situation will add to the stereotypical attitude that is in them. This can lead to the use of hate speech, incitement or use of violence against any group that is considered the 'carrier' of the epidemic such as blaming Chinese, Tabligh groups, migrants and refugees. This situation can lead to the destruction of unity between multiracial and religious communities. Unbeknownst to them, the act of transmitting fake news and acting on the fake news can lead to tyranny (Wan Mohd Nor, 2020).

The effects can be overcome by not trusting too much information from social media. To date, the Communications and Multimedia Commission (MCMC) has identified more than 1,000 fake news spreads in the country. Fake news is not only misleading, but can even threaten the safety of the people and the country. It does not only occur in Malaysia, but also in the United States, Indonesia and European countries (Ismail Sualman, 2020).

\section{Conclusion}

Spreading fake news is like spreading COVID-19 virus. The effects and consequences of this act are serious enough to affect public order. In this regard, it is important for the Malaysian Communications and Multimedia Commission (MCMC) to find the best mechanism in monitoring fake news so that this 'epidemic' does not spread and continue to affect national security. In receiving or conveying information, the truth and authenticity of a news must go through several processes in order to study and examine the news. Therefore, some factors that should be taken into account include being careful in conveying the news obtained before disseminating it so that there is no misunderstanding and error of facts in a news. The struggle to stop fake news is far from over and the community needs to be educated every day through various platforms including social media and mainstream media in the country. People are very happy to share whatever they receive, but the community should first check the information received, think and see if it is true or otherwise.

\section{Reference}

Adam Kucharski. (2020). Here's why we need Covid models, even if they are controversial. Retrieved $\quad$ September $\quad 17, \quad 2020, \quad$ from 


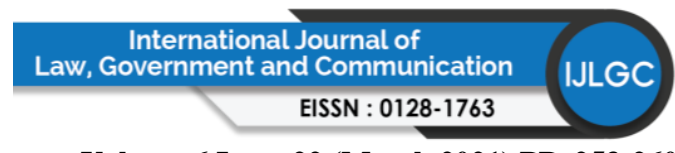

Volume 6 Issue 22 (March 2021) PP. 253-260

DOI 10.35631/IJLGC.6220024

https://www.theguardian.com/commentisfree/2020/nov/11/covid-data-imperfectscientists-projections.

Allcott, H., \& Gentzkow, M. (2017). Social media and fake news in the 2016 election. Journal of Economic Perspectives, 31(2), 211-236.

Allyn, M. R. (2003). Computers, gender, and pay1. The Journal of Business and Economic Studies, 9(2), 33.

Al-Sukkar, A. S. (2005). The application of information systems in the Jordanian banking sector: a study of the acceptance of the Internet. Wollongong, Australia: University of Wollongong Thesis Collection.

Amir Mamat, (2020). Jangan buat pembelian panik. Retrieved November 29, 2020, from https://www.hmetro.com.my/mutakhir/2020/11/639519/jangan-buat-pembelian-panik.

Asyikin Md Isa, (2020). 44 individu maut kerana percaya 'petua cegah' Covid-19, jangan main share saja! Retrieved November 29, 2020, from https://hellodoktor.com/coronavirus/covid19/berita-palsu-covid-19-janganpercaya/\#gref.

Björn Ross. (2018). Fake News on Social Media: The (In) Effectiveness of Warning Messages. $39^{\text {th }}$ International Conference on Information Systems, San Francisco: 1-17. Retrieved Mar 29, 2020 from https://www.researchgate.net/publication/328784235.

David Steano, (2020). Covid's-19 impact on mental health. Retrieved October 24, 2020, from https://winnipeg.ctvnews.ca/video?clipId=1937744.

Deuze, M., Bruns, A., and Neuberger, C. (2007). Preparing for an Age of Participatory News. Journalism Practice, (1:3), pp. 322-338.

Farris Shahiran Mohd Rizal, (2019). Faktor yang menyumbang dan cara mengatasi penyebaran berita palsu. Universti Tun Hussein Onn Malaysia.

Giselle, R. \& Turki A. (2020). Fake news: Acceptance by demographics and culture on social media. Journal of Information Technology \& Politics, 17(1), 1-11.

Howell, L. (2013). Digital wildfires in a hyperconnected world. Global Risks 2013. Retrieved September 4, 2018 from http://reports.weforum.org/global-risks-2013/riskcase- 1/digital-wildfires-in-a-hyperconnected-world/.

HM, (2020). Wartawan tak bertauliah gian jadi pelapor utama. Retrieved November 18, 2020, from https://mykmu.net/2020/11/18/wartawan-tak-bertauliah-gian-jadi-pelaporpertama/.

Ismail Sualman, (2020). Angkara media sosial. Retrieved October, 13, 2020, from https://www.sinarharian.com.my/article/61925/KOLUMNIS/Angkara-media-sosial,

Karim, F., \& Rampersad, G. (2017). Factors Affecting the Adoption of Cloud Computing in Saudi Arabian Universities. Computer and Information Science, 10(2), 109-123.

Li, S., Records, H., \& Fougere, K. (2004). An exploratory investigation of gender difference in student selection of a CIS minor. Issues in Information Systems, 5(2), 598.

Marchi, R. (2012). With Facebook, blogs, and fake news, teens reject journalistic "objectivity". Journal of Communication Inquiry, 36(3), 246-262.

M. Saraswathi, (2020). Penyebaran maklumat salah, berita palsu boleh jejas kekuatan ekonomi. Retrieved September 2, 2020, from https://www.utusanborneo.com.my/2020/02/10/penyebaran-maklumat-salah-beritapalsu- boleh-jejas-kekuatan-ekonomi.

Muzaffar Syah Mallow, (2020). Pembelian panik cetus keadaan lebih buruk. Retrieved November 29, 2020, from https://www.bharian.com.my/rencana/komentar/2020/03/666440/pembelian-panikcetus- keadaan-lebih-buruk. 
Volume 6 Issue 22 (March 2021) PP. 253-260 DOI 10.35631/IJLGC.6220024

Nurul Hidayah Bahaudin, (2020). SKMM kesan 43 penyebaran berita palsu Covid-19. Retrieved November 29 , 2020 , from https://www.hmetro.com.my/mutakhir/2020/03/557707/skmm- kesan-43-kespenyebaran-berita-palsu-covid-19.

Roberto Cavazos, (2019). Exclusive: Fake news is costing the world $\$ 78$ billion a year. Retrieved November 23, 2020, from https://cheddar.com/media/exclusive-fakenews-is-costing-the- world-billion-a-year.

Sapora Sipon, (2020). Berita palsu Covid-19 cetus ketakutan psikologi. Retrieved October 30, 2020, from https://www.bharian.com.my/authors/oleh-prof-dr-sapora-sipon?page=1.

Sarfarizmal Saad, (2020). Berita palsu tentang Covid-19 keruhkan lagi situasi pandemik. Retrieved November, 2, 2020, from https://www.sepatahdua.my/2020/10/28/berita-palsu-tentang- covid-19keruhkan-lagi-situasi-pandemik/.

Wan Mohd Nor, (2020). Usah rumitkan keadaan dengan sebar berita palsu. Retrieved November 29, 2020, from https://www.bharian.com.my/kolumnis/2020/10/745207/usah-rumitkan- keadaandengan-sebar-berita-palsu. 